\title{
構造用材料の溶接残留応力分布におよぼす 溶接諸条件の影響*
}

\author{
佐 藤 邦彦** 寺䗁 俊 夫**
}

\section{Effect of Welding Conditions on Residual Stresses Distributions in Welded Structures Materials*}

\author{
by Kunihiko, Satoh** and Toshio Terasaki**
}

It is well known that residual stresses due to welding influence the initiation of weld cracks and the strength of welded structures. In the present report, attention is forcussed to the effect of welding conditions on residual stress distributions in single-Vee-groove weld.

Analysis and experiments described below are conducted:

(1) Analysis of weld thermal stresses is carried out based on the thermo-elasto-plastic analysis by the finite element method. The residual stress distributions are obtained under the various conditions, such as weld heat input, plate width and thickness.

(2) Experiments on residual stress distributions are carried out. Experiments are obtained under various materials and the various conditions such as welding current, welding speed, plate width plate thickness and length.

The results obtained in this report are summarized as follows:

(1) Residual stress distributions are determined by parameters:

(a) Average temperature $T_{a p}^{*}=\alpha_{0} Q / 2 c \rho \varepsilon_{Y_{0}} h W$

(b) Initial temperature $\theta_{i}^{*}=\alpha_{0} \theta_{i} / \varepsilon_{Y_{0}}$

(c) Temperature above which yield strength becomes zero $\theta_{\boldsymbol{M}}^{*}=\alpha_{0} \theta_{M K} / \varepsilon_{Z_{0}}$

Comparing of the experimental results with calculated results give evidence that parameters $T_{a v}^{*}, \theta_{M}^{*}$ determines residual stress distributions.

(2) Residual stress distributions are classified two patterns according to average temperature. Residual stress distributions are mainly determined by average temperature in the same material.

(3) Conventional formulae are presented for the calculation of residual stress distributions produced in single-Vee-groove weld.

\section{1. 緒雫}

本研究は Fig. 1 亿示すような細長い長方形板のグル 一ブ溶接による残留応力分布におよぼす溶接諸条件の影 響を論じたものである.この種の溶接継手は溶接战留応 力の発生機構を明らかにする場合の対象として古くから 取り上げられており，多くの研究赫告がなされている。 溶揬入熱などの绦件が残留奻力分布におよぼす影饗につ いては过 ${ }^{1}$ が研呪を行ない，溶接入熱が溶接線(Fig.1の $x$ 朝）に沿って橓間投与されると仮想した一次元熱弾塑 性解析の手法によって溶接線方向残留応力の分布と溶接 入熱の関係を論じている.しかし，辻の研品では，板幅

*原搞受付 昭和50年10月14日（昭和49年度秋季全国大会にて発表）

** 正 員 大阪大学工学部 Member, Faculty of Engineer. ing, Osaka Univ.

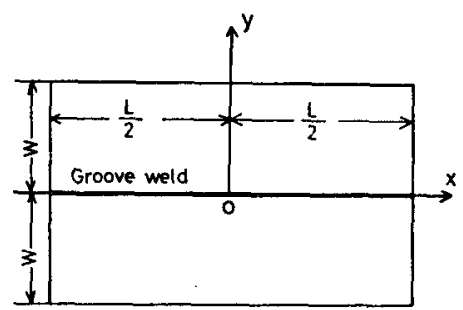

Fig. 1 Specimen for single-Vee-groove weld

$2 W の 1$ 枚の板の上に熱が投与されると仅定しており， 材料の変形抵抗がきわめて小さくなる高温においては板 幅 Wの2枚の板がそれぞれ独立に変形し得るというグ ルーブ溶接特有の現象を無視しているため, 求められた 残留応力分布之くに王縮応力を受ける母材部分の分布形 状は，たとえば Tall2) らが行なった実䮖結果や Fig. 2 


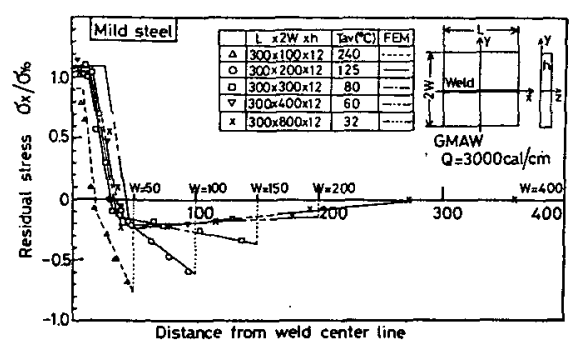

Fig. 2 Distributions of residual stress in groove welds of mild steel

に示す著者らの実験結果之はかならずしむ一致しない。 殴縮応力をうける母材部分を含めた板全体の残留応力の 分布と大きさにおよ济す溶接諸条件の影響を明らか代す るととが本研究の主たる目的である。

この目的のために本研究では上述のグルーブ溶接特有 の現象を考㯺に入れて，二次元 FEM 熱弹塑性解析を行 なった。まず，残留応力分布に影響をおよぼす諸要因に ついて検討し，溶接諸条件之材料定数を含むアパラメータ を見出し，実験との比較考察を行なった，次に，てのパ ラメータを用いて残留応力分布を比較的簡単に推定でき る算式を見出した。

\section{2. 残留応力分布を整理するためのパラ $x-y$}

Fig. 1 亿示すような長さ $L$, 幅 $W$, 板厚 $h$ の 2 枚の 細長い長方形板をその長刃に沿ってグルーブ溶接する場 合を対象として，残留応力分布を規定するパラメータに ついて考察する.

残留応力分布汇影響する要因を見出すため，一次元熱 弾塑性応力問題に関する辻”の研究にならって、ひずみ ・応力・温度・材料定数などについて Táble 1 亿示す ような無次元変数を使用する．これらの無次元変数を使

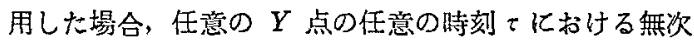

Table 1 Dimensionless Variables used in Thermo-elasto plastic study

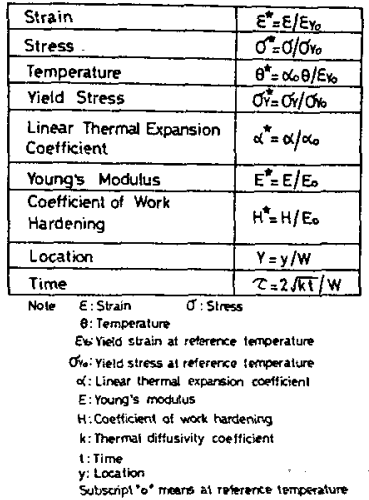

元化された応力・ひずみが同じになるためには次の $2 つ$ の条件が同時化成立しなければならない3).

(1) 温度 $\theta^{*}=\theta^{*}(\tau, Y)$ の履整が同じであること

(2) 材料定数 $\sigma_{Y}^{*}, \alpha^{*}, E^{*}, H^{*}$ の温度 $\theta^{*}$ に関する低存 性が同じであること

まず上記の条件》について考察する．Fig. 1 亿示す溶 接継手を想定し，本研究では熱源の移動効果を無視して $x$ 軸上认強さ $Q / h\left(\mathrm{cal} / \mathrm{cm}^{2}\right)$ の平面熱源が瞬間投与され る之仮想する．乙の場合 $Y$ 軸上の任意の点の任意の時 刻て亿おける温度 $\theta$ * は板表面加らの熱放散を無視する と次式で与えられる。

$$
\theta^{*}-\theta_{i}^{*}=2 T_{a v}^{*}\left[u_{p}(\tau, Y)+\sum_{n=1}^{\infty} u_{p}(\tau, Y \pm 2 n)\right]
$$

ただし

$\left.\begin{array}{cc}T_{a v}^{*}=\alpha_{0} T_{a v} / \varepsilon_{Y_{0}} T_{a v}=Q / 2 c \rho h W: \text { 板の平均温度上䒜 } \\ \theta_{i}^{*}=\alpha_{0} \theta_{1} / \varepsilon_{Y_{0}} & \theta_{i}: \text { 板の初期温度 } \\ u_{p}\left(\tau, Y^{\prime}\right)=\frac{1}{\sqrt{\pi} \cdot \tau} e^{-Y^{\prime 2} / \tau^{2}} & \end{array}\right\}$

式 (1) からわかるように，瞬間平面熱源が投与された という初期条件を用いるかぎり，温度 $\theta *$ の履歴は板の 平均温度上昇 $T_{a v}^{*}$ 之板の初期温度 $\theta_{i}^{*}$ に上って決定さ

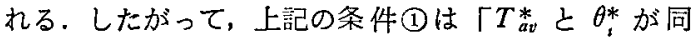
じであること」と書きかえるてとができる.

次に上記の条件(2)について考察する，材料定数 $\sigma_{Y}^{*}$ $\alpha^{*}, E^{*}, H^{*}$ の温度低存性が残留応力におよぼす影響を 知るため, Fig. 1 亿抽いて $L=300 \mathrm{~mm}, W=100 \mathrm{~mm}$, $h=10 \mathrm{~mm}$ とし， $x$ 軸上 $K Q / h=3000 \mathrm{cal} / \mathrm{cm}^{2}$ の平面熱 源が瞬間投与され， $\theta_{i}=0^{\circ} \mathrm{C}$ の場合について解析を行な ってみた．解析には二次元 FEM 熱弾塑性プログラムを 使用し, Table 1 に示した無次元変数を二次元応力場に 対して拡張使用して， $Y$ 軸上の残留応力 $\sigma_{x}^{*}\left(=\sigma_{x} / \sigma_{Y_{0}}\right)$ の分布を求めた．乙の場合，材料定数の温度依存性とし て Fig. 3 亿示吉 4 つの形式のものを採用した.すすね ち, 温度 $\theta_{M r}^{*}\left(=\alpha_{0} \theta_{M r} / \varepsilon_{Y_{0}}\right)$ 以上では材料は応力をうけ もたないものとし

Case 1 材料定数 $\sigma_{Y}^{*}, \alpha^{*}, E^{*}, H^{*}$ 少すべて線型の 温度依存性をもち， $\theta_{\mathrm{ar}}^{*}=6.7$ の場合

Case $2 \sigma_{Y}^{*}$ 以外の材料定数が温度に整関係に一定 で, $\theta_{u r}^{*}=6.7$ の場合

Case 3 上記と同様で $\theta_{\mathrm{u}}^{*}=3.3$ の場合

Case $4 \quad \sigma_{1}{ }^{*}$ の温度依存性が図に示すような 2 本の直 線で与えられ $\theta_{\text {粆 }}^{*}=6.7$ の場合

について数值解析した。なお， $x$ 軸上の温度が $\theta_{\text {M }}^{*}$ 以 上では板幅 $W の 2$ 枚の板が別々に変形するという条件 を解析に導入した。 

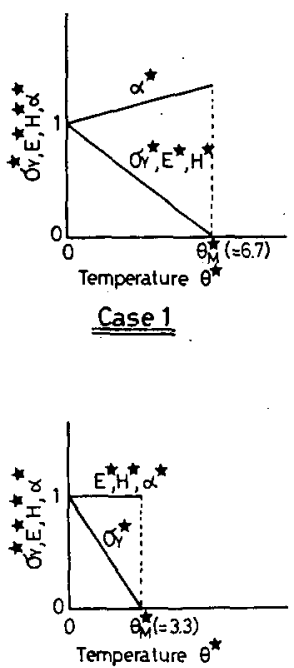

Case 3

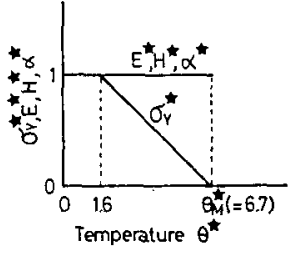

Case 4

Fig. 3 Temperature dependence of physical and mechanical properties selected for thermo-elasto-plastic analysis

解析結果を Fig. 4 に示す. 図からわかるように， Case 3 を除いては残留応力分布の形状はほぼ同一であ り，残留灾力の大きさの差はたかだか10\%以内におさま っている.とのととから，残留応力分布に主として影響 を与えるのは材料が応力をうけもたなくなる温度 $\theta_{M}^{*}$ であって， $\theta_{i}^{*}$ と $\theta_{\Delta x}^{*}$ の間における材料定数の変化の特

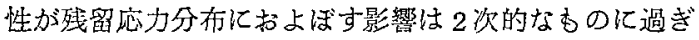
ないように思われる、したがって上記の条件(2は「材料

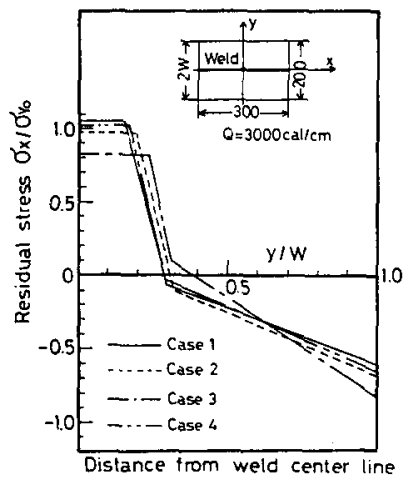

Fig. 4 Distributions of residual stress for selected temperature dependence of physical and mechanical properties

が応力をうけもたなくなる温度 昰が同じであること」 上書き加えてもよ加万う。

以上の考察による上, 残留态力 $\sigma_{x}^{*}=\sigma_{x}^{*}(Y)$ を規定 するパラメー夕は $T_{a v}^{*}, \theta_{i}^{*}$ および $\theta_{M}^{*}$ であり, 同一材 料では $T_{a v}$ と $\theta_{i}$ であると結論される。

\section{3. 実験}

軟鋼 (SS41)，Al 合金 (Al 5083-O)，オーステナイト 系ステンレス鐝 (AISI 310S) の3種の材料を用い, Table 2 亿示すように板の長さ $L$, 板幅 $W$, 板屌 $h$ お よび溶接入熱 $Q$ の種々の組合せについて奏験を行なっ た. 溶接は GMAWによるグルーブ単揗溶接である。 板の初期温度は $15 \sim 25^{\circ} \mathrm{C}$ の範囲であった。残留応力 $\sigma_{x}$ を求めるには溶接後, 板の中央断面を中心として溶接線

Table 2 Experimental conditions

\begin{tabular}{|c|c|c|c|c|c|c|c|c|}
\hline \multirow[t]{2}{*}{ Material } & \multirow{2}{*}{$\begin{array}{l}\text { Specimen } \\
\text { number }\end{array}$} & \multirow{2}{*}{$\begin{array}{c}\text { Length } \\
L(\mathrm{~mm}) \\
\end{array}$} & \multirow{2}{*}{$\begin{array}{l}\text { Width } \\
2 W(\mathrm{~mm})\end{array}$} & \multirow{2}{*}{$\begin{array}{c}\text { Thickness } \\
\mathrm{n}(\mathrm{mm})\end{array}$} & \multicolumn{3}{|c|}{ Welding Conditions } & \multirow{2}{*}{$\mathrm{T}_{\mathrm{av}}\left({ }^{\circ} \mathrm{C}\right)$} \\
\hline & & & & & $I(A)$ & $V(V)$ & $\mathrm{v}(\mathrm{cm} / \mathrm{min})$. & \\
\hline \multirow[t]{4}{*}{$\$ \$ 41$} & $\begin{array}{l}\text { ML1 } \\
\text { ML2 } \\
\text { ML3 } \\
\text { ML4 }\end{array}$ & $\begin{array}{l}100 \\
200 \\
300 \\
400\end{array}$ & $\begin{array}{l}200 \\
200 \\
200 \\
200\end{array}$ & $\begin{array}{l}12 \\
12 \\
12 \\
12 \\
\end{array}$ & $\begin{array}{l}435 \\
445 \\
445 \\
435 \\
\end{array}$ & $\begin{array}{l}25 \\
25 \\
25 \\
25 \\
\end{array}$ & $\begin{array}{l}35 \\
35 \\
38 \\
35 \\
\end{array}$ & $\begin{array}{l}131 \\
134 \\
125 \\
131 \\
\end{array}$ \\
\hline & $\begin{array}{l}\text { MW1 } \\
\text { MW2 } \\
\text { Mw3 } \\
\text { Mw4 } \\
\text { Mw5 }\end{array}$ & $\begin{array}{l}300 \\
300 \\
300 \\
300 \\
300\end{array}$ & $\begin{array}{l}100 \\
240 \\
300 \\
400 \\
800 \\
\end{array}$ & $\begin{array}{l}12 \\
12 \\
12 \\
12 \\
12 \\
\end{array}$ & $\begin{array}{l}435 \\
435 \\
430 \\
435 \\
435 \\
\end{array}$ & $\begin{array}{l}25 \\
24 \\
25 \\
25 \\
25\end{array}$ & $\begin{array}{l}38 \\
30 \\
38 \\
38 \\
35 \\
\end{array}$ & $\begin{array}{r}240 \\
122 \\
80 \\
60 \\
32 \\
\end{array}$ \\
\hline & $\begin{array}{l}\mathrm{MQ1} \\
\mathrm{MQ2} \\
\mathrm{MQ3}\end{array}$ & $\begin{array}{l}300 \\
300 \\
300\end{array}$ & $\begin{array}{l}200 \\
200 \\
200\end{array}$ & $\begin{array}{l}12 \\
12 \\
12\end{array}$ & $\begin{array}{l}455 \\
438 \\
420 \\
\end{array}$ & $\begin{array}{l}25 \\
25 \\
25\end{array}$ & $\begin{array}{l}23 \\
23 \\
56\end{array}$ & $\begin{array}{r}210 \\
153 \\
80 \\
\end{array}$ \\
\hline & $\begin{array}{l}\text { MT1 } \\
\text { MT2 } \\
\text { MT3 } \\
\text { MT4 } \\
\text { MT5 } \\
\text { MT6 } \\
\text { MT7 }\end{array}$ & $\begin{array}{l}450 \\
450 \\
450 \\
300 \\
300 \\
300 \\
300 \\
\end{array}$ & $\begin{array}{l}300 \\
300 \\
300 \\
200 \\
200 \\
200 \\
400 \\
\end{array}$ & $\begin{array}{l}15 \\
15 \\
15 \\
10 \\
10 \\
10 \\
12 \\
\end{array}$ & $\begin{array}{l}450 \\
435 \\
435 \\
455 \\
455 \\
450 \\
425\end{array}$ & $\begin{array}{l}24 \\
24 \\
25 \\
25 \\
24 \\
24 \\
25 \\
\end{array}$ & $\begin{array}{l}31 \\
21 \\
20 \\
30 \\
35 \\
42 \\
38\end{array}$ & $\begin{array}{r}78 \\
111 \\
122 \\
114 \\
157 \\
130 \\
58 \\
\end{array}$ \\
\hline A15083-0 & $\begin{array}{l}\text { AL1 } \\
\text { AL2 } \\
\text { AL3 } 3 \\
\text { AL4 } \\
\text { AL5 } \\
\end{array}$ & $\begin{array}{l}300 \\
300 \\
300 \\
300 \\
300 \\
\end{array}$ & $\begin{array}{l}200 \\
200 \\
200 \\
200 \\
400 \\
\end{array}$ & $\begin{array}{l}10 \\
10 \\
10 \\
10 \\
10 \\
\end{array}$ & $\begin{array}{l}220 \\
220 \\
230 \\
135 \\
220 \\
\end{array}$ & $\begin{array}{l}26 \\
27 \\
27 \\
24 \\
27 \\
\end{array}$ & $\begin{array}{l}40 \\
60 \\
49 \\
30 \\
60 \\
\end{array}$ & $\begin{array}{r}120 \\
82 \\
105 \\
88 \\
41 \\
\end{array}$ \\
\hline AlsI310S & $\begin{array}{l}\text { SS1 } \\
\text { SS2 } \\
\text { SS3 } \\
\text { SS4 }\end{array}$ & $\begin{array}{l}300 \\
300 \\
300 \\
300\end{array}$ & $\begin{array}{l}200 \\
200 \\
200 \\
200\end{array}$ & $\begin{array}{l}10 \\
10 \\
10 \\
10\end{array}$ & $\begin{array}{l}220 \\
210 \\
215 \\
205\end{array}$ & $\begin{array}{l}27 \\
27 \\
31 \\
27\end{array}$ & $\begin{array}{l}40 \\
26 \\
32 \\
43\end{array}$ & $\begin{array}{r}76 \\
114 \\
109 \\
67\end{array}$ \\
\hline
\end{tabular}


に平行に標点距離 $60 \mathrm{~mm}$ のコンタクトボールを打ち込 んだ後開放し，開放前後の標点距離の变化加ら求めたひ ずみに䌅弹性係数をかけるという単純な方法によった。 実験結果を整理するために必要な材料定数を一括して Table 3 に示す. Table 3 の定数值を用いて, 各試験片 の平均温度上昇 $T_{a v}$ を計算した結果を Table 2 の右欄 に示してある。

Table 3 Physical and Mechanical properties

\begin{tabular}{|c|c|c|c|}
\hline & Mild steet & $A 15083-0$ & AISI $310 \mathrm{~S}$ \\
\hline$c($ cali $/ \mathrm{C} \cdot g)$ & 0.13 & 0.23 & 0.12 \\
\hline$\rho\left(g / c m^{3}\right)$ & 7.8 & 2.64 & 8.03 \\
\hline$E_{o}\left(\mathrm{~kg} / \mathrm{mm}^{2}\right)$ & 21000 & 7100 & 20400 \\
\hline$\sigma_{V_{d}\left(\mathrm{~kg} / \mathrm{mm}^{2}\right)}$ & 31 & 148 & 28 \\
\hline$\varepsilon_{Y_{0}}\left(=\sigma_{\left.\gamma_{0} / E_{0}\right)}\right.$ & $1.48 \times 10^{3}$ & $2.11 \times 10^{-3}$ & $1.38 \times 10^{-3}$ \\
\hline$\alpha_{0}\left({ }^{\circ} \mathrm{C}^{-1}\right)$ & $1.2 \times 10^{5}$ & $2.38 \times 10^{5}$ & $1.75 \times 10^{-5}$ \\
\hline$\theta+\left({ }^{2} \mathrm{C}\right)$ & 830 & 430 & 950 \\
\hline$Q^{*}\left({ }^{\circ} \mathrm{C}\right)$ & 6.7 & 4.6 & 12.1 \\
\hline $\begin{array}{l}E_{0:} \\
\sigma_{v_{0}:} \\
E_{r_{0}} \\
\theta_{m}: \\
\alpha_{0}:\end{array}$ & $\begin{array}{l}\text { folure ax } \\
\text { thermal }\end{array}$ & c & zers. \\
\hline
\end{tabular}

\section{4. 実験結果と考察}

\section{1 残留応力分布の型}

前项の実験は初期温度 $\theta_{i}=15 \sim 25^{\circ} \mathrm{C}$ ほ ば一定で行な われているので, 残留応力分布はそれぞれの材料でとに 板の平均盜度上景 $T_{a v}$ によって定まると予想される。

Fig. 5 (a)，(b)，(c) ほ使用した 3 種の材料の残留応力 の測定值を平均温度上鼠 $T_{a v}$ の比較的低い場合子高い 場合について， $Y(=y / W)$ に対してプロットしたむの である，図においてろつの折机線であらわした直線は FEM 二次元熱弾塑性解析 の結果を直線で結んだもので あって，実験值ときわわて上い一致を示している.罒(a) の $T_{a v}=125^{\circ} \mathrm{C}$ の実験值はそれぞれ板幅, 板厚, 入熱が 翼なっているにむかかわらずほぼ一本の曲線に乗ってお $\eta$, 平均温度上昇 $T_{a v}$ が同じならば残留応力分布 $\sigma_{x}^{*}=$ $\sigma_{x}^{*}(Y)$ が同一になるととを示している.

Fig. 5 によるよいずれの材料でもその残留応力行布は 平均温度上昇 $T_{a v}$ の高低によっておおむね Fig. 6 の 2
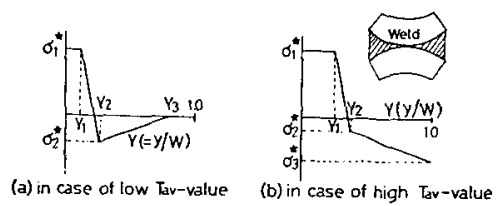

Fig. 6 Residual stress patterns obtained by experiments

理類に大別できる。このと亡は溶接金属の変形抵抗が きわめて小さくなる高温の状態 $\left(\theta \geqq \theta_{\text {M }}\right)$ では板幅 $W$ の2枚の板が Fig. 6 (b)の図中に示すようにそれぞれ別 個に変形するというグルーブ容接特有の現象に基因する あのである.

\section{2 残留応力分布の略算式}

残留応力分布を Fig. 6 亿示したように3本の折机線 であらわすならば，図に示す $\sigma_{1}{ }^{*}, \sigma_{2}{ }^{*}, \sigma_{3}{ }^{*} お$ よび $Y_{1}$, $Y_{2}, Y_{3}$ の值を知ることによって残留応力分布を求める ことができる。

実験に使用した軟鋼，Al 合金，ステンレス鋼の残留 応力 $\sigma_{1}{ }^{*}, \sigma_{2}{ }^{*}, \sigma_{3}{ }^{*}$ および位置 $Y_{1}, Y_{2}, Y_{3}$ 之平均温度上 杽 $T_{a v}$ の関係を FEM 二次元熱弾塑性解析によって求め た結果と実験值とをあわせて示すと Fig. 7 (a)，(b)，(c) のようになる、実験值と計算値とは拈拈むねよい一致を 示している.

てれらの実験值と計算值から次のようなととがいえ

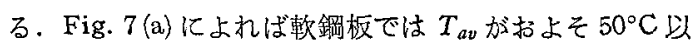

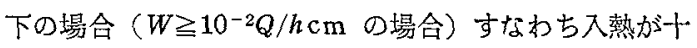
分小さいか板幅が十分大きい場合には， $\sigma_{1} *=1.0 \sim 1.1$, $\sigma_{2}{ }^{*}=-0.25, \sigma_{3}{ }^{*}=0$ で残嵧応力分布は Fig. $6(\mathrm{a})$ の型 の分布となる. との場合には Fig. 7 (a) に示すように $Y_{1}, Y_{2}, Y_{3}$ は $T_{a v}$ にほぼ比例して増加しており，したが って $y_{1}, y_{2}, y_{3}$ は板幅 $W$ 亿無関係で入熱 $Q / h$ 亿比例 することがわかる．Fig. 7 (a) からこの比例定数を求め, 残留応力値上ともにまとめると Table 4のようになる. 次に, Fig. 7 (a) において $T_{a v}$ がおよそ $150^{\circ} \mathrm{C}$ 以上の

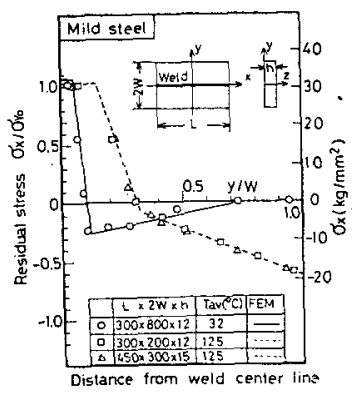

(a) Mild steel

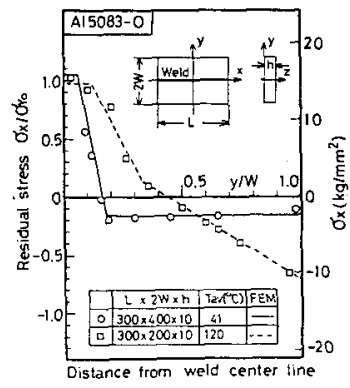

(b) Alalloy

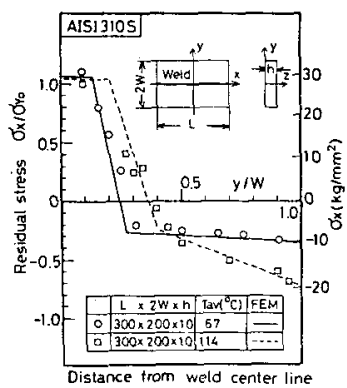

(c) Stainless steel

Fig. 5 Distributions of residual stress 

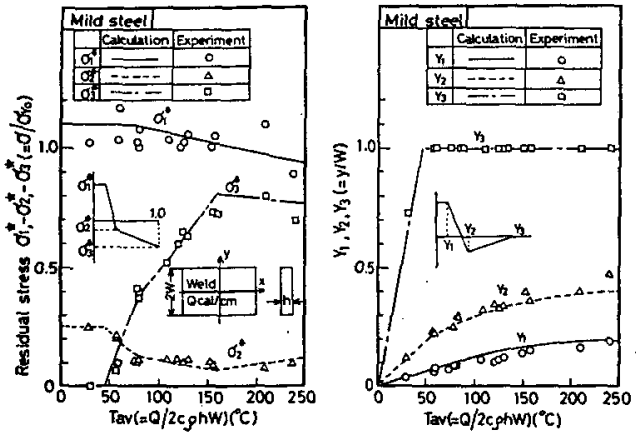

(a) Mild steel
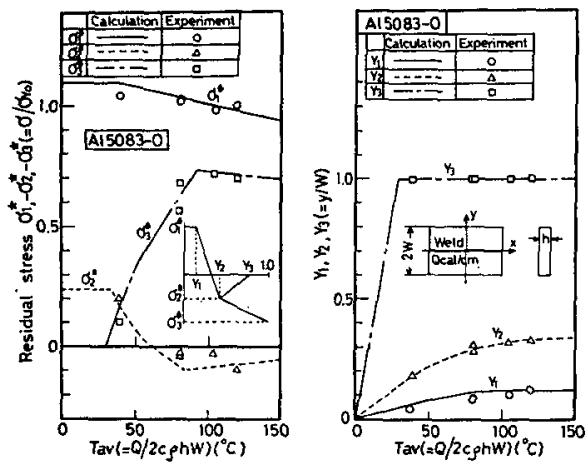

(b) Alalloy
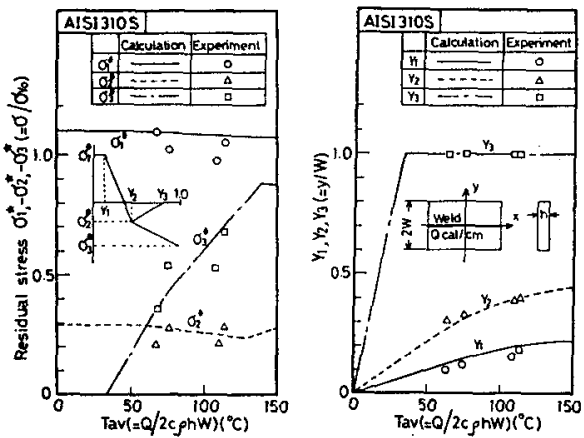

(c) Stainless steel

Fig. 7 Effect of average temperature $T_{a v}$ on residual stress $\sigma_{1}^{*}, \sigma_{2}^{*}, \sigma_{3}^{*}$ and locations $Y_{1}, Y_{2}, Y_{3}$.

場合 ( $W \leqq 0.33 \times 10^{-2} Q / h \mathrm{~cm}$ の場合) すなわち入熱が 十分に大きいか板幅が十分小さい場合には $\sigma_{1}^{*} \fallingdotseq 0.9 \sim$ 1.1， $\sigma_{2}{ }^{*}=-0.1 ， \sigma_{3}^{*} \doteqdot-0.8$ で残留応力分布は Fig. 6 の (b) 型の分布になる.乙の場合には Fig. 7 (a) に示す ように $Y_{1}, Y_{2}, Y_{3}$ は $T_{a v}$ に簬関係にほぼ一定であり， したがって $y_{1}, y_{2} ， y_{3}$ は入熱に無関係で板幅 $W$ に比例 することがわかる. Fig. 7 (a) からこの比例定数を求め, 残留応力值とと屯にまよると Table 4 のようになる. $T_{a v}$ が $50^{\circ} \mathrm{C}$ と $150^{\circ} \mathrm{C}$ の間では残留応加分布は上に述
Table 4 Residual Stress Pattern for Groove Weld of Selected Materials

\begin{tabular}{|c|c|c|c|c|}
\hline Material & $\begin{array}{c}\text { Width of plate } \\
(\mathrm{cm})\end{array}$ & pattern & $\begin{array}{l}\text { Residual } \\
\text { stress }\left(\mathrm{kg} / \mathrm{mm}^{2}\right)\end{array}$ & $\begin{array}{l}\text { Location } \\
\text { (cm) }\end{array}$ \\
\hline \multirow[t]{2}{*}{$\begin{array}{l}\text { Mild steel } \\
\text { (SS41) }\end{array}$} & $w \geq 10^{-2} \mathrm{O} / \mathrm{h}$ & Fig. $5(a)$ & $\begin{array}{l}\sigma_{1}=(10 \sim 1.1) \sigma_{\gamma_{0}} \\
\sigma_{2}=-0.25 \sigma_{r_{0}} \\
\sigma_{3}=0\end{array}$ & $\begin{array}{l}y_{1}=0.6 \times 10^{-3} \mathrm{O} / \mathrm{h} \\
y_{2}=2.0 \times 10^{-3} \mathrm{Q} / \mathrm{h} \\
y_{3}=11 \times 10^{-3} \mathrm{Q} / \mathrm{h}\end{array}$ \\
\hline & $W \leq 0.33 \times 10^{-2} \mathrm{o} / \mathrm{h}$ & Fig. $6(b)$ & $\begin{array}{l}\sigma_{1}=(0.9-1.1) \sigma_{\gamma_{0}} \\
\sigma_{2}=-0.1 \sigma_{\gamma_{0}} \\
\sigma_{3}=-0.8 \sigma_{\gamma_{0}}\end{array}$ & $\begin{array}{l}y_{1}=0.18 w \\
y_{2}=0.4 W \\
y_{3}=w\end{array}$ \\
\hline \multirow[t]{2}{*}{$\begin{array}{l}\text { Al-alloy } \\
\text { (Al5083-0) }\end{array}$} & $\mathrm{W} \geq 2.7 \times 10^{-2} \mathrm{O} / \mathrm{h}$ & Fig. 6(a) & $\begin{array}{l}\sigma_{1}=(1.0-1.1) \sigma_{\gamma_{0}} \\
\sigma_{2}=-0.24 \sigma_{10} \\
\sigma_{3}=0\end{array}$ & $\begin{array}{l}y_{1}=0.8 \times 10^{-3} \mathrm{Q} / \mathrm{h} \\
y_{2}=2.3 \times 10^{-3} \mathrm{O} / \mathrm{h} \\
y_{3}=18 \times 10^{-3} \mathrm{O} / \mathrm{h}\end{array}$ \\
\hline & $\mathrm{w} \leq 0.9 \times 10^{-2} \mathrm{Q} / \mathrm{h}$ & Fig $6(b)$ & $\begin{array}{l}\sigma_{t}=(0.9-1.1) \sigma_{Y_{0}} \\
\sigma_{2}=0.05 \sigma_{Y_{0}} \\
\sigma_{3}=-0.7 \sigma_{t_{0}}\end{array}$ & $\begin{array}{l}y_{1}=0.12 W \\
y_{2}=0.30 w \\
y_{3}=w\end{array}$ \\
\hline \multirow[t]{2}{*}{$\begin{array}{l}\text { Stainless } \\
\text { steel } \\
\text { (AISI310S) }\end{array}$} & $w \geq 1.5 \times 1 \sigma^{-2} \mathrm{O} / \mathrm{h}$ & Fig 6(a) & $\begin{array}{l}\sigma_{1}=(1.0 \sim 1.1) \sigma_{\gamma_{0}} \\
\sigma_{0}=-03 \sigma_{r_{0}} \\
\sigma_{3}=0\end{array}$ & $\begin{array}{l}y_{1}=1.0 \times 10^{-3} \mathrm{Q} / \mathrm{h} \\
y_{2}=2.2 \times 10^{-3} \mathrm{Q} / \mathrm{h} \\
y_{3}=15 \times 10^{-3} \mathrm{Q} / \mathrm{h}\end{array}$ \\
\hline & $w \leq 0.4 \times 10^{-2} \mathrm{Q} / \mathrm{h}$ & Fig. 6(b) & $\begin{array}{l}\sigma_{1}=(1.0 \sim 1.1) \sigma_{\gamma_{0}} \\
\sigma_{2}=-0.25 \sigma_{\gamma_{0}} \\
\sigma_{3}=-0.9 \sigma_{\gamma_{0}}\end{array}$ & $\left\{\begin{array}{l}y_{1}=0.22 w \\
y_{2}=0.45 w \\
y_{3}=w .\end{array}\right.$ \\
\hline
\end{tabular}

ベた 2つの中間の様相を示す. すなわち $\sigma_{1}^{*} \div 1.0 \sim 1.1$, $\sigma_{2}^{*}=-0.1$ で $\sigma_{3}^{*}$ は $T_{a v} の$ 上昇ととすに 0 からおよ そ -0.8 まで变化する. 一方 $y_{1}$ と $y_{2}$ はどちらかとい えば板幅に無関係で入熱 $Q / h$ に比例するが， $y_{3}$ は入熱 に無関係で $y_{3}=W$ である。

Al 合金板 (Fig. 7(b))，オーステナイト采ステンレス 鋼板（Fig. 7 (c)）の溶接残留応力分布についても上述の 軟鋼板と類似の特性が認められる.これらの材料につい て上と同様に残留応力分布を求めるのに必要な諸舅を計 算した結果を Table 4 に示す.

\section{3 三種の材料の残留応力分布の比較}

実験に使用した三種の材料の残留応力分布の特性を比 較考察する目的で，2節で述べた考察に基づき，Fig. 7 の横皕を $T_{a v}^{*}\left(={ }_{0} \alpha T_{a v} / \varepsilon_{Y_{0}}\right)$ 亿换算して示守と Fig. 8 のようになる。四に示すように $T_{a v}^{*}$ が同じであっても 材料の $\theta_{M}^{*}\left(=\alpha_{0} \theta_{\mu} / \epsilon_{Y_{0}}\right)$ が暴なると残留応力分布はか ならずしす同一にはならないしかし，T加十分に小
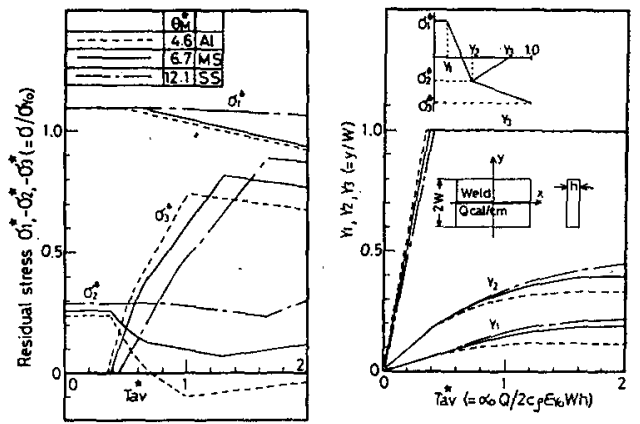

Fig. 8 Effect of dimensionless average temperature $T_{a v}^{*}$ on residual stresses $\sigma_{1}^{*}, \sigma_{2}^{*}$, $\sigma_{3}{ }^{*}$ and locations $Y_{1}, Y_{2}, Y_{3}$ 
さい場合, す广わち, $T_{a v}^{*} \leqq 0.4$ の庆幅溶接継手の場合

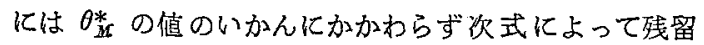
応力分布のおよその傾向を求めることができる.

$$
\left.\begin{array}{rlrl}
\sigma_{1}{ }^{*} & =1.0 \sim 1.1, & & y_{1}=0.075 \alpha_{0} Q / c \rho \varepsilon_{Y_{0}} h \\
-\sigma_{2}{ }^{*}=0.25 \sim 0.3, & y_{2}=0.22 \alpha_{0} Q / c \rho \varepsilon_{Y_{0}} h \\
\sigma_{3}{ }^{*} & =0, & & y_{3}=1.3 \alpha_{0} Q / c \rho \varepsilon_{Y_{0}} h
\end{array}\right\}
$$

\section{5. 残留応力分布におよぼす初期温度 $\theta_{i}$ の影響}

初期温度 $\theta_{i}$ が残留応力分布におよばす影響を FEM 二 次元熱弹塑牲解析により調べた. Fig. 9 は平均温度上昇 $T_{a v} 25^{\circ} \mathrm{C}$ の軟鋼板について $\theta_{i}$ を $0^{\circ} \mathrm{C} \sim 200^{\circ} \mathrm{C}$ と变化さ がせて， $\theta_{i}$ が残留応力 $\sigma_{1}{ }^{*}, \sigma_{2}{ }^{*}, \sigma_{3}{ }^{*} お$ おび位置 $Y_{1}$, $Y_{2}, Y_{3}$ におよぼす影響を示したすのである。图に示す 上うに引張最大応力 $\sigma_{1}{ }^{*}$ は $\theta_{i}$ の上昇之ともにやや減少 するが，その他の值は $\theta_{i}$ によって目立った変化を示さ ず，したがって残留応力分布の全般的な傾向は $\theta_{i}$ によ ってほとんぞ影響をうけないといえる。
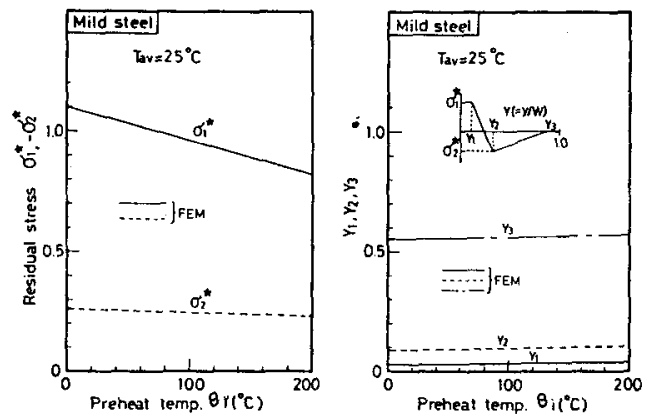

Fig. 9 Effect of initial temperature (preheat temperature) $\theta_{1}$ on residual stresses $\sigma_{1}^{*}, \sigma_{2}^{*}$ and locations $Y_{1}, Y_{2}, Y_{3}$

\section{6. 残留応力分布におよぼす溶接長の影響}

以上の計算と実験は Fig. 1 に示す長方形板において 溶接長 $L$ が十分に長い場合についてであった. 溶接 長 $L$ が短い場合には端部効果のために板の中央断面

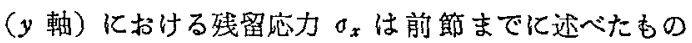
より小さくなるはずである. $y$ 軸上の残留応力 $\sigma_{x}$ が端 部効果をうけない最小の溶接長 $L_{c r}$ を求めるため, 次に 述べるような計算を行なった。すなわち，まず半無限板 の端面に Fig. 10 の図中に示すような釣合った外応力を

$$
\left.\begin{array}{l}
\sigma_{x}=-\sigma_{Y_{0}}\left(0 \leqq|y| \leqq y_{1}\right) \\
\sigma_{x}=\frac{y_{1}}{y_{3}-y_{1}} \sigma_{Y_{0}}\left(y_{1} \leqq|y| \leqq y_{3}\right)
\end{array}\right\}
$$

作用させた場合の $x$ 軸上に扔ける $x$ 方向応力 $\Delta \sigma_{x}$ を計 算する。 $\Delta \sigma_{z}$ は板の端面からの距離的で零となるが，便

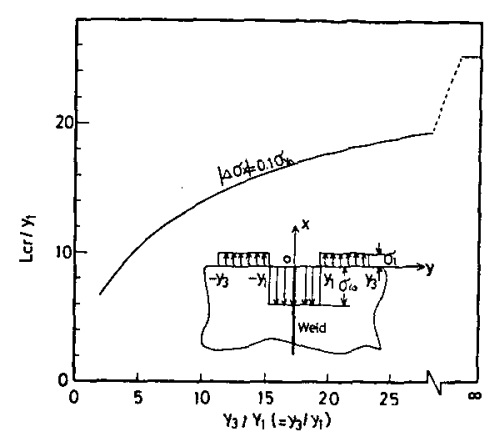

Fig. 10 Relation between critical weld length and locations

宜上 $\left|\Delta \sigma_{x}\right|=0.1 \sigma_{Y_{0}}$ になる板の端面加らの距離を求め, その 2 倍を $L_{c r}$ とした. とのようにして計算した $L_{c r}$ は $y_{3} / y_{1}$ の值によって Fig. 10 のように変化する. Fig. 10 上 Fig. 7 あるいは Fig. 8 とを組合せると，与えられ た溶接諸条件に対して $L_{c r}$ を求めるとよができる.

一例として，T粦ミ0.4なる十分な広幅の溶接継手を 考元る. ての場合, Fig. 8 より $Y_{3} / Y_{1} \div 17$ であり, し たがって Fig. 10 から

$$
L_{c r}=17 y_{1}=y_{3}
$$

式（3）上り

$$
L_{c r}=1.3 \alpha_{0} Q / c \rho \varepsilon_{Y_{0}} h
$$

と求められる.

上に述べた $L_{c}$ の推定の妥当牲を実跧によって検討す る. Fig. 11 は Table 2 において溶接長の影響を調べた ML シリーズの実験結果である.ML シリーズでは平鸤 温度上昇は約 $130^{\circ} \mathrm{C}$ であり, Fig. 7 上 Fig. 10 から $L_{c r}$ を求めると $18 \mathrm{~cm}$ となる. 残留応力の測定は標点距離 $6 \mathrm{~cm}$ で行なっているので, $L_{c r}=18+6=24 \mathrm{~cm}$ 以上の 溶接長で残留応力の測定值はほぼ変化しなくなる，との ことは Fig. 11 の実験結果とほぼ一致している。

日本造船研究協会 SR147 部会ではその研究の一部之 して造船用鋼板 (降代応力 $25 \sim 40 \mathrm{~kg} / \mathrm{mm}^{2}$ ) の溶接残 留応力を測定している゙). この実験では溶接長 2000〜 $2250 \mathrm{~mm}$ ，板幅 $1000 \mathrm{~mm}$ ，板厚 $25.4 \mathrm{~mm}$ の板を 2 枚, 入熱 $Q=108 \sim 195 \mathrm{KJ} / \mathrm{cm}$ でグルーブ溶接し, 溶接部の 溶接線方向の残留応力分布を調べている. 以上の溶接諸 条件の場合，大部分の溶接継手で $T_{a v}^{*} \leqq 0.4$ の条件が 成立し， $L_{c r}$ は式 (5) で与えられる.すなわち，板端 部から $36 \sim 50 \mathrm{~cm}$ 内部にはいると溶接線上の応力はほ ぼ一定になると予想される。.SR147 の実験值は32〜 $50 \mathrm{~cm}$ 板端部から内部にはいるとほぼ一定となってお り、上記の推定とほぼ一致する。 


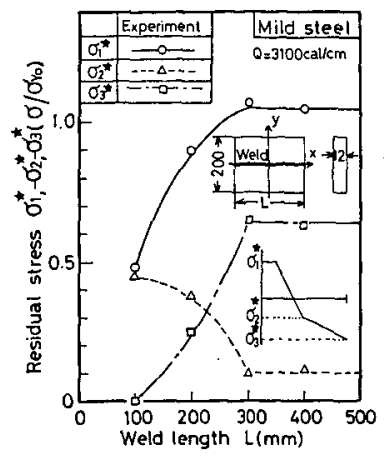

Fig. 11 Effect of weld length on residual stresses

\section{7. 結 論}

本論文で得られた結論を要約すると次の通りである。

（1）グルーブ溶接の残留応力分布は

平均温度上昇の無次元パラメータ $T_{a v}^{*}=\alpha_{0} Q / 2 c \rho \varepsilon_{Y_{0}} h W$

初期温度の無次元パラメータ $\quad \theta_{i}^{*}=\alpha_{0} \theta_{i} / \varepsilon_{Y_{0}}$

降伏応力が零になる温度の無次元パラメータ

$$
\theta_{M}^{*}=\alpha_{0} \theta_{M} / \varepsilon_{Y_{0}}
$$

で規定される。

同一材料では

$\begin{array}{ll}\text { 平均温度上昇 } & T_{a v} \\ \text { 初期温度 } & \theta_{i}\end{array}$

で規定される。

（2）残留灾力分布は平均温度上昇の高低によっておお むね Fig. 6 の 2 種類に大別できる。
（3）平均温度上昇 $T_{a v}$ ・で軟鋼， $\mathrm{Al}$ 合金，オーステナ イト系ステンレス鋼の残留応力分布を整理し，残 留応力分布を求める略算式を導いた（Table 4 参 照)

（4）平均温度上梸の無次元パラメータ $T_{a v}^{*}$ で三種の 材料の残留応力分布を整理し，広幅溶接継手で

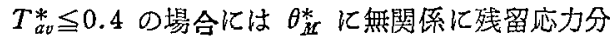
布は略算式 (3) で求められることを示した。

（5）初期温度 $\theta_{i}$ は $\theta_{i}=0 \sim 200^{\circ} \mathrm{C}$ の範困では残留応 力分布に影響定与えない(軟銅の場合).

（6）板中央の残留応力分布が変化しなくなる溶接長 $L_{c r}$ は入熱, 板厚, 板幅, 材料定数の関数となり, 平均温度上昇の無次元パラメータ $T_{a v}^{*}$ で残留応力 分布を整理した Fig. 8 亡 Fig. 10 上り求められ る. $T_{a v}^{*} \leqq 0.4$ のとき

$L_{c r}=1.3 \alpha_{0} Q / c \rho \varepsilon_{Y_{0}} h$ (軟鋼板では $L_{c r}=$ $\left.0.33 Q / h \sigma_{Y_{0}}\right)$

となる。

\section{参考 文 献}

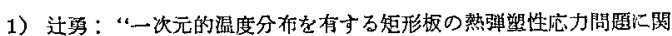

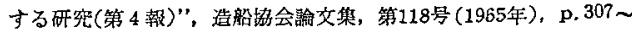
p. 317

2) N.R. Nagaraja Rao and Lambert Tall: "Residual Stresses in Welded Plates", W. J., Vol. 40 (1961年), No. $10,468 \mathrm{~s} \sim 480 \mathrm{~s}$

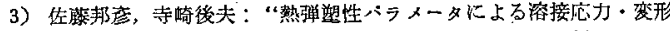
の研究”，本誌，第44巻(1975年)，第 2 号，p. 31〜p. 36 (昭和50 年春率大会シンポジム)

4) SR 147 (1975年)“，船体用高㖘力銅板大入热溶接継手の脆性破榩

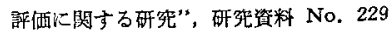

New Publication from the Japan Welding Society

\section{ADVANCED WELDING TECHNOLOGY}

Proceedings of the Second International Symposium of the

Japan Welding Society held in Osaka, August, 1975

Maintopics are as follows; High Energy Density Beam Welding, High Power Welding and Cutting, Advanced Technology for Welding and Cutting, Automatic Control for Welding and Cutting, Solid State Welding.

It includes 110 papers and those discussions. To be published in Jannuary, 1976, Approx. 700 pages, $210 \times 297 \mathrm{~cm}$, Price 30,000 Yen (IIW Members and Booksellers) 